\title{
Spectrophotometric Determination of $\mathrm{Trace} \mathrm{Hg}(\mathrm{II})$ in Cetyltrimethylammonium Bromide Media
}

\author{
Moon-Sook Jeoung and Hee-Seon Choi \\ Department of Chemistrv. The Cniversity of Sin'on, P.O. Box 77, Sin'on 445-743, Korea \\ Received June 24, 2004
}

\begin{abstract}
The simple and convenient detemination of trace $\mathrm{Hg}$ (II) with its 2-mercaptobenzothiazole (MBT) conplex in cetyltrimethylammonium bromide (CTAB) media has been studied. The UV-visible spectrum of $\mathrm{Hg}(\mathrm{II})-\mathrm{MBT}$ complex in CTAB media had a good sensitivity and reproducibility. The $\mathrm{Hg}$ (II)-MBT complex in CTAB solution was very stable at $\mathrm{pH} 10.0$ and could be quantitatively contexed if MBT were added to the sample solution more than 10 equivalent of $\mathrm{Hg}$ (II). The optimum concentration of CTAB was $0.001 \%$. The calibration curve of $\mathrm{Hg}(\mathrm{II})-\mathrm{MBT}$ complex with good linearity $\left(\mathrm{R}^{2}=0.9985\right)$ was obtained at the concentration range between $1.0 \times 10^{-5}$ and $1.0 \times 10^{-5} \mathrm{M}$ in $0.001 \% \mathrm{CTAB}$ media. The detection limit was $3.1 \times 10^{-8} \mathrm{M}(6.2 \mathrm{ng}$ $\left.\mathrm{mL}^{-1}\right) . \mathrm{Hg}(\mathrm{II})$ in the synthetic samples and in the wastewater of the university's wastewater tank and the industrial wastewater tank could also be determined. Based on the experimental results, this proposed technique could be applied to the simple and convenient determination of trace $\mathrm{Hg}$ (II) in real samples.
\end{abstract}

Key Words : Mercury. 2-Mercaptobenzothiazole, Cetyltrimethylanmonium bronide (CTAB). UV-Visible spectrophotometry

\section{Introduction}

Mercury is so volatile that it could be exposed easily to human enviromment. It would cause a neurological damage

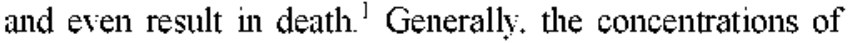
$\mathrm{Hg}$ in envirommental samples are relatively low unless exposed in some industrial area. Total mercury concentrations in natural waters ranged from 0.2 to $100 \mathrm{ng} \mathrm{L}^{-1}$ ? while methylmercury levels were known to even lower level, about $0.05 \mathrm{ng} \mathrm{L}^{-1}$. ${ }^{3}$ However, mercury in contaminated environmental materials may exist at levels of micrograms per liter. The simple and convenient methods are required to permit the determination of $\mathrm{Hg}$ (II) in the contaminated samples. Techniques which can determine low concentration of mercury in water and biological materials have been developed. including inductively coupled plasma mass spectrometry 4.5 inductively coupled plasma atomic emission spectrometry ${ }^{67}$ cold vapor atomic absorption spectrometry. ${ }^{8.5}$ and anodic stripping voltammetry. ${ }^{11}$

In some techniques the preconcentration should be performed to determine ultratrace $\mathrm{Hg}(\mathrm{II})$. However these procedures could reduce the accuracy of the determination and require a longer time in handling of sample. Among these preconcentration techniques, cold vapor atomic absorption spectrometry has widely been used ${ }^{1.12}$ with merits such as high sensitivity and little interference effects. but has somewhat poor precision and accuracy ${ }^{13}$ Inductively coupled plasma-atomic emission spectrometry and inductively coupled plasma-mass spectrometry are useful in determining ultratrace $\mathrm{Hg}$ (II) without preconcentration. ${ }^{14.15}$ However. these instruments are very expensive and costly for the maintenance.

\footnotetext{
Corresponding Author. e-mail: choihsiä
}

To determine trace $\mathrm{Hg}(\mathrm{II})$ with UV-visible spectrometry various chelating agents such as dithizone ${ }^{16 i}$ diphenylcarbazone.$^{17}$ and di- $\beta$-naphthylthiocarbazone ${ }^{18}$ have been used. This technique should be performed with solvent extractions that are time-consuming and tedious. have lower accuracy and precision. and usually involve harmful solvent One of these widely used teclniques is dithizone method But this method has limitations due to the serious interference by $\mathrm{Cu}(\mathrm{II})$ as well as the photosensitivity of the mercury-dithizonate complex. ${ }^{19}$

Organic micellar media are very useful in analytical applications. including the improved analyte sensitivity in UV-visible spectrometric methods ${ }^{2(-23}$ and in fluorescence methods and quenching processes. ${ }^{2+}$ Especially, the surfactants have been used to improve UV-visible spectrophotometric determination of metal ions with complexing agents. Generally. the metal-chelate complexes formed in the surfactant media are more stable than those formed in the absence of surfactant ${ }^{25}$

In the present study. the convenient and simple determination of trace mercury(II) was spectrometrically performed with its 2-mercaptobenzothiazole complex in cationic CTAB media without an extraction procedure

\section{Experimental Section}

Instrumentation. A Hewlett-Packard 8453A single beam diode array spectrometer was used to measure the absorbance of $\mathrm{Hg}(\mathrm{II})-\mathrm{MBT}$ complex in CTAB media. To determine $\mathrm{Hg}(\mathrm{II})$ in university's wastewater samples. a HP 4500 ICP-MS spectrometer was also used. To adjust the $\mathrm{pHs}$ and prepare the buffer solution. a Bantex model $300 \mathrm{~A}$ digital $\mathrm{pH}$ meter equipped with a combined glass and calomel electrode was used. 
Reagents and solutions. All chemicals. such as $\mathrm{Hg}\left(\mathrm{NO}_{3}\right)_{2} \cdot \mathrm{H}_{2} \mathrm{O}$ (Fisher $\mathrm{Co}$.) and 2-mercaptobenzothiazole (MBT) (Wako Co.). were analytical or guaranteed-grade reagents. Standard $\mathrm{Hg}(\mathrm{II})$ was made from $10^{-2} \mathrm{M}$ stock solution. The stock solution of $\mathrm{Hg}(\mathrm{II})$ was made in $0.1 \mathrm{M}$ $\mathrm{HNO}_{3}$, and stored at less than $\mathrm{pH} 2.0$. A $0.01 \%(\mathrm{w} / \mathrm{v})$ cetyltrimethylanumonium bromide (CTAB) (BHD Co.) solution was prepared by dissolving $0.01 \mathrm{~g}$ of CTAB in a 100 $\mathrm{mL}$ volumetric flask with stirring: MBT solution was prepared by dissolving in ethyl alcohol to give a $10^{-3} \mathrm{M}$

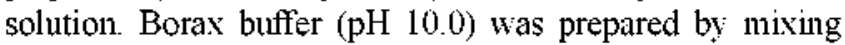
$0.025 \mathrm{M}$ borax and $0.1 \mathrm{M} \mathrm{NaOH}$. To investigate the interfering effects by various species. $1.0 \times 10^{-2} \mathrm{M}$ stock solutions were used. Deionized water prepared by a Barnstead sy'stem (Barnstead Co.) was used throughout all experimental procedures.

Calibration curve. Standard $\mathrm{Hg}(\mathrm{II})$ solutions were prepared in the range of $1.0 \times 10^{-7} \mathrm{M} \sim 1.0 \times 10^{-5} \mathrm{M}$. Several aliquots of $\mathrm{Hg}$ (II) standard solutions were taken in $10 \mathrm{~mL}$ volumetric flasks and $0.3 \mathrm{~mL}$ of $10^{-3} \mathrm{M} \mathrm{MBT}$ and $1.0 \mathrm{~mL}$ of $0.01 \% \mathrm{CTAB}$ were added to each flask. Then it was filled to the mark with borax buffer solution ( $\mathrm{pH} \mathrm{10.0)}$. After 30 minutes of leaving it as it stood a calibration curve of $\mathrm{Hg}$ (II) was constructed by a UV-visible spectrophotometer. The regression equation was obtained with the method of least squares. Using this linear equation. we determined the correlation coefficient $\left(\mathrm{R}^{2}\right)$ and the detection limit. The detection limit is defined as the sample concentration giving a signal equal to the blank average signal plus three times the standard deviation of the blanks. ${ }^{-6}$

Applications to real samples. The university wastewater and the industrial wastewater were taken as a real sample after suspended matter or particles were filtered out with a glass filter (1-G-1). A sỵnthetic sample was prepared so that the concentration of $\mathrm{Hg}(\mathrm{II})$ was $4.0 \times 10^{-6} \mathrm{M}$. that of $\mathrm{NaNO}_{3}$ was $5.0 \times 10^{-1} \mathrm{M}$. and that those of $\mathrm{Cu}\left(\mathrm{NO}_{3}\right)=\mathrm{Cd}\left(\mathrm{NO}_{3}\right)_{2}$. $\mathrm{Ni}\left(\mathrm{NO}_{3}\right)_{2}, \mathrm{Bi}\left(\mathrm{NO}_{3}\right)_{3}$ and $\mathrm{Pb}\left(\mathrm{NO}_{3}\right)_{2}$ were $1.0 \times 10^{-5} \mathrm{M}$. To determine $\mathrm{Hg}(\mathrm{II})$ with the method of standard addition. several $5.0 \mathrm{~mL}$ aliquots of the university wastewater. the industrial wastewater and the synthetic samples were taken in $10 \mathrm{~mL}$ volumetric flasks. Exactly $0.0 .0 .2,0.4 .0 .6,0.8$. and $1.0 \mathrm{~mL}$ of a standard solution containing $5.0 \times 10^{-5} \mathrm{M}$ of $\mathrm{Hg}$ (II) were also added to each flask. Then. $0.3 \mathrm{~mL}$ of $10^{-3}$ M EDTA. $0.3 \mathrm{~mL}$ of $10^{-3} \mathrm{M}$ MBT and $0.1 \mathrm{~mL}$ of $0.01 \%$ CTAB were added. and the flask was filled to the mark with borax buffer ( $\mathrm{pH} 10.0)$.

\section{Results and Discussion}

Absorption spectra of $\mathrm{Hg}(\mathrm{II})-\mathrm{MBT}$ complex. After $\mathrm{Hg}$ (II). MBT and CTAB were taken in a $10 \mathrm{~mL}$ volumetric flask so that their concentrations were $3.0 \times 10^{-6} \mathrm{M} .3 .0 \times$ $10^{-5} \mathrm{M}$ and $0.001 \%$. respectively the solution was diluted to

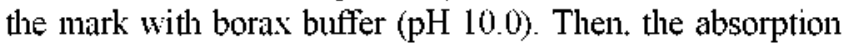
spectrum of $\mathrm{Hg}(\mathrm{II})-\mathrm{MBT}$ complex was obtained (Figure 1). The analytical sensitivity and the reproducibility in this spectrum were good in CTAB media. The phenomenon

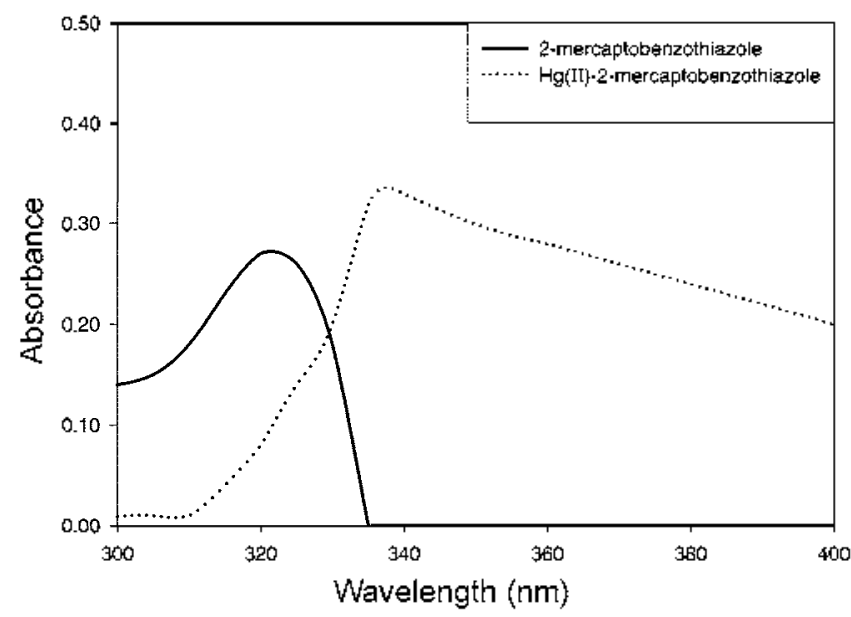

Figure 1. UV-Visible spectra of $\mathrm{Hg}$ (II) - 2-mercaptobenzothiazole $\left(3.0 \times 10^{-0} \mathrm{M}\right)$ and 2-mercaptobenzothiazole $\left(1.0 \times 10^{-5} \mathrm{M}\right)$ in $0.001 \%$ CTAB media at $\mathrm{pH} 10.0$.

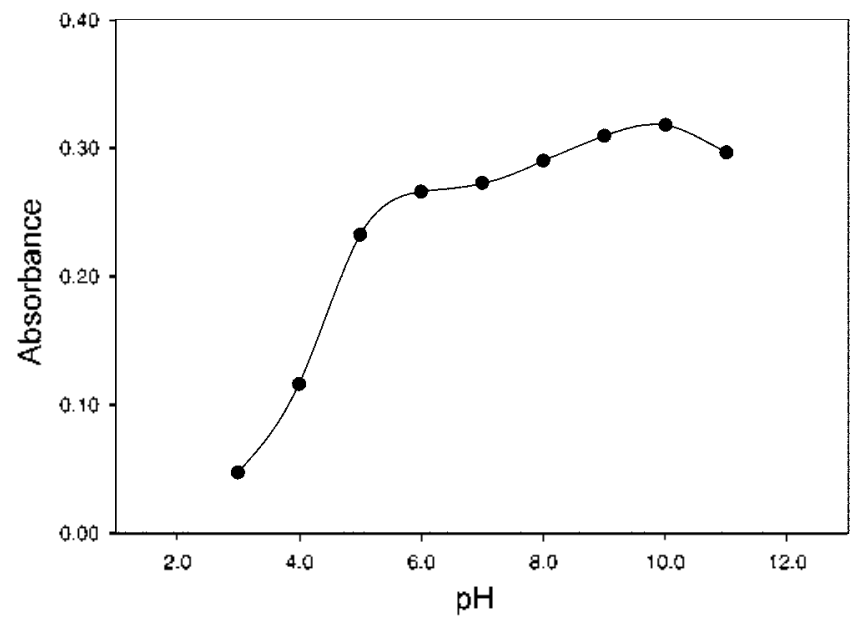

Figure 2. Effects of $\mathrm{pH}$ on the absorbance of $\mathrm{Hg}$ (II) - 2-mercaptobenzothiazole $\left(3.0 \times 10^{-6} \mathrm{M}\right)$ in $0.001 \%$ CTAB media.

seems to have been caused by the electrostatic and hydrophobic interactions between $\mathrm{Hg}(\mathrm{II})-\mathrm{MBT}$ complex and surfactant. ${ }^{27}$ And after $10 \mathrm{~mL}$ chloroform solution of $10^{-3} \mathrm{M}$ MBT was added to $10 \mathrm{~mL}$ of $3.0 \times 10^{-6} \mathrm{M} \mathrm{Hg}$ (II) solution which was buffered at $\mathrm{pH} 10.0 \mathrm{in}$ a $100 \mathrm{~mL}$ separatory funnel, it was shaked for $30 \mathrm{~min}$. Unfortunately, the reproducible absorption spectra of $\mathrm{Hg}$ (II)-MBT in chloroform could not obtained

$\mathrm{pH}$ effect. The influence of $\mathrm{pH}$ on the absorbance of Hg(II)-MBT $\left(3.0 \times 10^{-6} \mathrm{M}\right)$ complex in $0.001 \%$ CTAB media was investigated (Figure 2). Hg(II)-MBT complex showed the maximum absorption at $\mathrm{pH} 10.0$. From this result. we realize that $\mathrm{Hg}$ (II)-MBT complex was quantitatively formed and well dissolved in CTAB media at $\mathrm{pH} 10.0$. We assume that the reaction to form this complex could have competed against hy'droxide precipitation above $\mathrm{pH} 10.0$ and at acidic $\mathrm{pH}$. as the sulfur atom in the chelating site of MBT has more affinity power with proton at a higher concentration of protons.

Concentration of MBT. It is known that $\mathrm{Hg}$ (II) is 


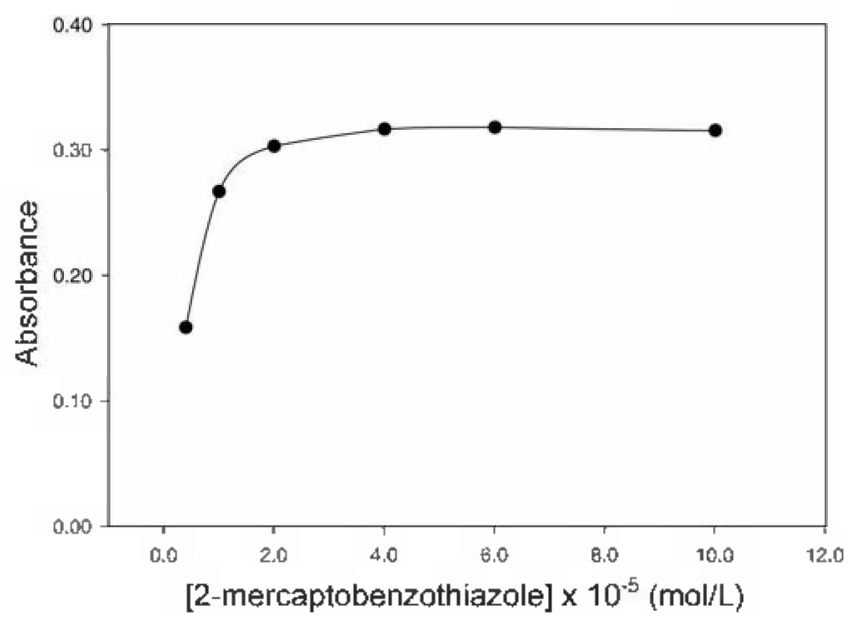

Figure 3. The absorbance changes of $\mathrm{Hg}$ (II) - 2-mercaptobenzothiazole $\left(3.0 \times 10^{-5} \mathrm{M}\right)$ on the concentration of 2-mercaptobenzothiazole in $0.001 \%$ CTAB media at $\mathrm{pH} 10.0$.

stoichiometrically combines with MBT to form $1: 2$ complex: ${ }^{28}$ For a metal complex to be formed quantitatively. however. one must add more chelating agent to the sample solution. Figure 3 shows how the absorbance of $\mathrm{Hg}(\mathrm{II})$ MBT complex changes with the concentration of MBT. We found that when MBT was added to more than 10 equivalent of $\mathrm{Hg}(\mathrm{II})$. the absorbance was high and constant

Concentration of CTAB. When the concentration of CTAB surfactant exceeds its critical micelle concentration. the homogeneous micelle solution is formed at a point where $\mathrm{Hg}(\mathrm{ll})-\mathrm{MBT}$ complex can be well dissolved. Due to high viscosity. the concentrated $\mathrm{CTAB}$ media was hard to handle. whereas those with low viscosity under diluted conditions could not form a micelle or make a homogeneous solution of complex as the polarity of aqueous solution was not lowered

With the concentration of $\mathrm{CTAB}$ varying from $0.0005 \%$ to $0.05 \%$ at $\mathrm{pH} 10.0$. the absorbance of $\mathrm{Hg}(\mathrm{II})\left(3.0 \times 10^{-6} \mathrm{M}\right)$ complex was investigated and the results are shown in Figure 4 . The maximum absorbance was obtained when the

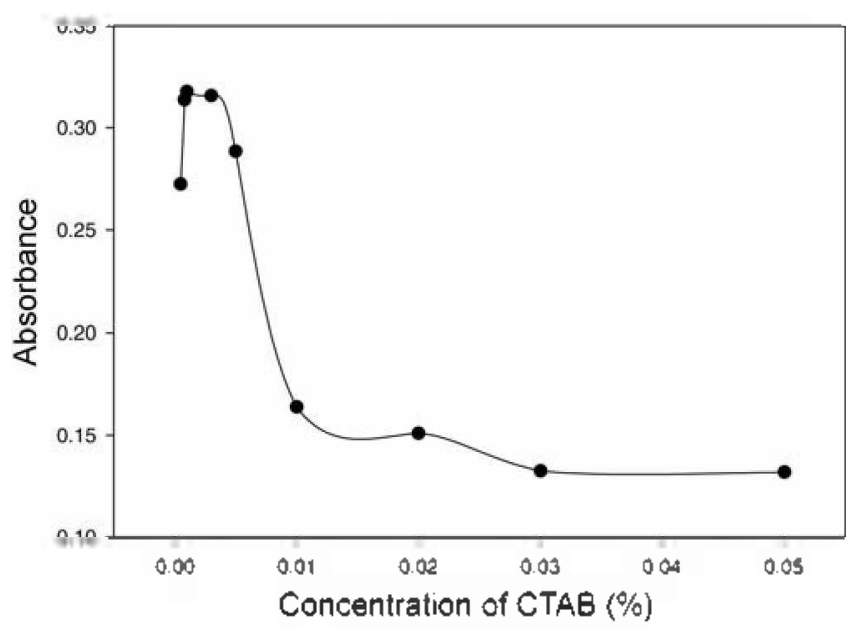

Figure 4. Effect of the concentration of CTAB on the $\mathrm{Hg}(\mathrm{II})-2$ mercaptobenzothiazole $\left(3.0 \times 10^{-6} \mathrm{M}\right)$ complex at $\mathrm{pH} 10.0$. concentration of $\mathrm{CTAB}$ was $0.001 \%$ to $0.003 \%$. We assumed that although the concentrations of these $\mathrm{CTAB}$ were somewhat less than critical micelles concentration $(0.0013$ M. $0.047 \%) .^{-9} \mathrm{Hg}(\mathrm{II})$-MBT complex was homogeneously dissolved in surfactant media. Here. the selected concentration of CTAB was $0.0001 \%$

To investigate the effect of types of surfactants. Triton X100 as nonionic and sodium dodecylsulfate as anionc surfactant were used. In given concentration range $(1.0 \times$ $\left.10^{-7} \mathrm{M} \sim 1.0 \times 10^{-5} \mathrm{M}\right)$. calibration curve of $\mathrm{Hg}$ (II)-MBT could not be obtained in both nonionic Triton X-100 and anionic sodium dodecylsulfate media. Cationic surfactants have been used rather than anionic or nonionic surfactants to determine metal ions by UV-Vis spectrophotometry. Because a metal ion is a cation. the electrostatic attractive interaction between a metal ion and cationic surfactant is not present. and the complex-forming process is not affected.

To investigate the stability of $\mathrm{Hg}(\mathrm{II})-\mathrm{MBT}$ complex in CTAB media at $\mathrm{pH} 10.0$. the absorbance was measured as the function of time. The absorbance decreased slowly from the beginning of measurement to $30 \mathrm{~min}(0.0013$ absorbance unit/min.) and after $30 \mathrm{~min}$. the variation of absorbance was not observed. It is assumed because the time that reached at dy'namic equilibrium between $\mathrm{Hg}(\mathrm{II})$-MBT complex and CTAB surfactant was relatively slow in incomplete micelle solution.

Interference effect. MBT combines with several metal ions such as $\mathrm{Cu}(\mathrm{II}), \mathrm{Bi}(\mathrm{III}) . \mathrm{Ni}(\mathrm{II})$ and so forth to form a stable and slightly soluble metal complex in aqueous solution. So, when $\mathrm{Hg}(\mathrm{II})$ is determined with MBT. the other metal ions in real samples may interfere with $\mathrm{Hg}$ complexforming. The possible interference effects of concomitant ions on the determination of $\mathrm{Hg}$ (II) were investigated under the optimum conditions given above and are shown in Table 1. Cu(II) and Bi(III) were interfered with more strongly than any other ions. and unfortunately, this interference could be partially $(\sim 5 \%)$ eliminated by adding EDTA to be $3.0 \times$ $10^{-5} \mathrm{M}$. However, when EDTA was added to be above $3.0 \times$ $10^{-5} \mathrm{M}$. the releasing effect was diminished. It is assumed that at $\mathrm{pH} 10 . \mathrm{Hg}$ (II) forms an MBT complex that is more stable than the corresponding EDTA complex and the EDTA complexes of $\mathrm{Bi}(\mathrm{III})$ and $\mathrm{Cu}(\mathrm{II})$ is more stable than their MBT complexes.

Application to real samples. This proposed technique is

Table 1. Tolerance limits" for interfering ions in $3.0 \times 10^{-6} \mathrm{M}$ $\mathrm{Hg}$ (II) solution

\begin{tabular}{cc}
\hline $\begin{array}{c}\text { Mole ratio of interfering ion to } \\
\mathrm{Hg}(\mathrm{II})\end{array}$ & Ions \\
\hline 100 & $\mathrm{SCN}^{-}, \mathrm{NH}_{3}$, \\
50 & $\mathrm{~S}_{2} \mathrm{O}_{3}^{2}, \mathrm{Cl}^{-}$ \\
25 & $\mathrm{Cd}(\mathrm{II}), \mathrm{Zn}(\mathrm{II}), \mathrm{Br}^{-}$ \\
10 & $\mathrm{Ni}(\mathrm{II}), \mathrm{Co}(\mathrm{II}), \mathrm{Pb}(\mathrm{II}), \mathrm{CN}^{-}, \mathrm{I}^{-}$ \\
5 & $\mathrm{Clu}(\mathrm{II}), \mathrm{Bi}(\mathrm{III})$ \\
\hline
\end{tabular}

Tolerance limit is the maximum mole ratio of interfering ion to $\mathrm{Hg}(\mathrm{II})$ in which the effect on the absorbance is less than $5^{\circ} .0$ 
Table 2. Analytical data of $\mathrm{Hg}(\mathrm{II})$ in real and synthetic samples by the standard addition method

\begin{tabular}{|c|c|c|c|}
\hline \multirow{2}{*}{ Samples } & \multicolumn{2}{|c|}{ Measured $(\mathrm{M})^{\prime}$} & \multirow{2}{*}{ Recovery yield (\%) } \\
\hline & This proposed method & ICP/MS & \\
\hline University wastewater & $\begin{array}{l}2.52( \pm 0.08) \times 10^{-9} \\
3.75( \pm 0.08) \times 10^{-9}\end{array}$ & $\begin{array}{l}2.43( \pm 0.09) \times 10^{-9} \\
3.68( \pm 0.09) \times 10^{-9}\end{array}$ & \\
\hline Industrial wastewater & $\begin{array}{l}1.83( \pm 0.08) \times 10^{-3} \\
2.02( \pm 0.09) \times 10^{-3}\end{array}$ & $\begin{array}{l}1.78( \pm 0.09) \times 10^{-9} \\
1.97( \pm 0.09) \times 10^{-9}\end{array}$ & \\
\hline Synthetic sample $\left(4.00 \times 10^{-5} \mathrm{M}\right)$ & $4.09( \pm 0.09) \times 10^{-5}$ & & 102.3 \\
\hline
\end{tabular}

"The average values were obtained from seven samples.

simpler and more easily applicable in determining $\mathrm{Hg}$ (II) in a solution than dithizone liquid extraction technique. A calibration curve was constructed at optimum conditions according to calibration curve procedure in experimental section. The dynamic range of $\mathrm{Hg}(\mathrm{II})$ was $1.0 \times 10^{-7} \mathrm{M}$ to $1.0 \times 10^{-5} \mathrm{M}$ and the regression equation was $1.046( \pm 0.008)$ $\times 10^{5} \mathrm{x}+0.002( \pm 0.001)$. The correlation coefficient $\left(\mathrm{R}^{2}\right)$ was 0.9985 . showing a good linearity of calibration curve. Based on the signals of twenty-five blank solutions and the slope of calibration curve. it was found that the detection limit was $3.1 \times 10^{-\delta} \mathrm{M}\left(6.2 \mathrm{ng} \mathrm{mL^{-1 }}\right)$.

The standard addition method was used to determine $\mathrm{Hg}$ (II) in real samples because of the incomplete release due to the interfering effects. $\mathrm{Hg}$ (II) in the wastewater at the university's wastewater tank and the industrial wastewater tank and in the synthetic sample were determined by this proposed technique and the results are shown in Table 2 . The relative standard deviations representing the reproducibility were less than $5.0 \%$ in these measurements. $\mathrm{Hg}$ (II) in the university wastewater samples and the industrial wastewater samples were also determined by ICP-MS spectrometry. At $95 \%$ confidence level. no difference between results from the proposed and ICP-MS methods had been established. Therefore. this proposed technique could be applied to the determination of a ppb level of $\mathrm{Hg}$ (II) in real samples.

\section{Conclusions}

By using of $\mathrm{Hg}(\mathrm{II})-\mathrm{MBT}$ in CTAB bromide media. a ppb level of $\mathrm{Hg}$ (II) could be determined simply, conveniently and reproducibly. Results from the proposed method and ICP-MS method were slightly different. In conparison with dithizone extraction method that was time-consumed. tedious and using harniful solvent, this technique had not those limitations but showed higher sensitivity. Detection linit and relative standard deviation of the measured data were

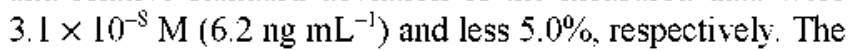
proposed teclnnique could be applied to the deternination of $\mathrm{Hg}$ (II) in real samples.

\section{References}

1. Manahan. S. E. Enirommental Chemistry 6th Ed.. Lewis
Publisher: Boca Raton. U.S.A.. 1994: p 184.

2. Cossa. D.: Sanjuan. J.: Cloud. T.: Stochwell. P. B.: Toms. W. T. J. Anal. Atom. Spectront 1995. 10.287.

3. Horvat. M. Liang, L.: Bloom. N. S. Anal Chim. Acta 1993. 282. 153.

4. Schmit. J.: Youla. M.: Gelinas. Y. Anal. Chim Acta 1991. 249.495.

5. Karunasagar. D.: Arunachalam. T.: Gangadharan. S. J. Anal. Afon Spectront 1998. 13.679.

6. Vijayakimar. M.: Ramakrishn1a. I. V: Aravamudan1. G. Talanta $1980,27,911$

7. Saouter. E. Anal Chem 1994, 66, 2031.

8. Schnitzer. G; Soubelet. A.: Chafey. C. Mikrochim Acta 1995. 119. 199.

9. Manzoori. J. L.: Sorouraddin. M. H.: Shabani. A. M. H. J. Anal. Aron. Spectron. 1998.13.305.

10. Ugo. P: Moretto. L.: Bertochello. P.: Wang. T. Electroamalysis 1998. 10,1017 .

11. Katiuska, A:; Marinela, C: Roman. M: Jose. D: Hilda. L.; Elizabeth, G.; Lenin, H. Fresenius I. Anal Chem 1996. 355, 319.

12. Bermojo-Barrera. P.: Moreda-Pineiro. T.: Moreda-Pineiro. A.: Bermejo-Barrera. A. J Anal Atont. Spectront 1997. 12.317.

13. Eaton. A. D.: Clesceri. L. S.: Greenberg. A. E. Standand Methods for the Examination of Water and Wastewater: 19 th Ed: American Public Health Association: Washington. U.S.A., 1995: pp 3-19.

14. Passariello, B.: Barbaro. M.: Quaresima, S.: Cascielo. A.; Marabini, A. Aicrochent. J. 1996. 54. 348.

15. Michael. K.: Herbert. R.: Irgolic. K. T. Fresentus J. Anal. Chen. 1996. 355. 120 .

16. Kozelka. F. L. Anal Chem 1947. 19.494.

17. Laird. F. W: Smith. A. Ind. Eng. Chem, Anal. Ed 1938. 10. 576.

18. Cholak. J.: Hubbard. D. M. Ind. Eng. Chem. Anal. Ed. 1946, 18. 149.

19. Eaton. A. D.: Clesceri. L. S.: Greenberg. A. E. Standord Methods for the Examination of Water and Watevater: 19th Ed: American Public Health Association: Washington. U.S.A., 1995: pp 3-79.

20. Lee. S.: Choi, H. Bull. Korean Chem. Soc. 2001, 22. 463.

21. Park. S.: Choi, H. Anal. Chim Acta 2002, 459.75.

22. Choi. Y.: Choi. H. Bull. Korew Chem. Soc. 2003. 2+. 222

23. Yun1. J.: Choi. H. Talamta 2000. 52.893.

24. Turro. N. J.: Gratzel. M.: Brauti. A. M. Angew. Chem. Int Ed. Engl. $1980,19,675$.

25. Diaz Garcia. M. E.: Sanz-Medel. A. Talanta 1986. 33, 255.

26. Skoog. D. A.: Holler, F. J.: Nieman, T. A. Principles of Instrumental Analowis. 5th Ed.: Saunders College Publishing: Philadelphia. U.S.A. 1998: $p 13$.

27. Esteve-Romero. J. S.: Monferrer-Pons. L.: Ramis-Ramos. G.: Garcia-Alvarez-Coque. M. C. Talanta 1995. 42,737.

28. Spacu. G.: Kuras. M. Z. Anal Chem 1936. 102, 108.

29. Cline Love. L. J; Dorsey. J. G.: Habarta. J. G. Anal. Chem. 1984. 56. 1132A.

30. Jarosz. M.: Marczenko. Z. Anot.st 1984. 109. 35. 